\title{
THIN CAPITALIZATION: FINANCIAL INNOVATION VERSUS TAX RULES
}

\author{
Ivan A. Darushin \\ St. Petersburg State University, Russia \\ Natalia S. Voronova \\ St. Petersburg State University, Russia
}

\begin{abstract}
The needs of companies in capital cheapening lead to the emergence of new financing patterns. One of such patterns based on the substitution of equity capital by the debt capital is hidden or thin capitalization. When used within a framework of a group of companies the cheapening of financing takes place by reducing the overall tax burden. However, this mechanism conflicts with fiscal interests of the state, forcing it to develop new tax regulations. On the other hand, any additional regulation leads to the feedback from financial market. In case of thin capitalization, it is manifested in the emergence of new hybrid forms of financing and new financial instruments to avoid or mitigate the impact of fiscal restraints. This article is dedicated to the research of thin capitalization mechanisms, the causes of its appearance and use. The state's interest in regulating the thin capitalization is reasoned, the main trends and rules of its regulation are identified. Separately some new financial instruments that appeared as response to tax regulation are explored.
\end{abstract}

Keywords: financing, thin capitalization, financial innovation, tax regulation

JEL code: H210, G180

\section{Company's financing and thin capitalization}

The main forms of external business financing are equity and debt funding. The choice of a particular form of financing is determined by a lot of factors that take into account the interests both of investors and the company feeling the need for additional funding. One of such factors is tax implications for transaction parties.

Within the framework of equity and debt financing capital raising generates a payment of two different types of income for investors, namely, dividends and interest.

Dividends are paid from retained profit of a company, while the interest on borrowed funds is operational expense on debt service and, accordingly, the source of their payment is a pre-tax profit. Thus, funding from contributions to the equity capital entails double economic taxation. Investors income is actually taxed twice, first as a part of a profit paid to the company prior to its distribution and then as income in the form of dividends. It should be noted that the negative effects of double taxation may be partially (but not completely) offset by a lower tax rates applicable to dividends.

If using debt financing the paid interest reduces the tax base when calculating the income tax. They are subject to the so-called tax shield that allows you to reduce the effective cost of raised debt capital in accordance with the current income tax rates. As a result, the final costs of debt capital raise are lower than the interest rate actually paid by the borrower.

The interest on loan, obtained by an investor, are included in his taxable base, in other words, the redistribution of tax burden in his favor takes place. In this case, the investor pays income tax, which in case of debt financing was to be paid by the company raising the capital. But in fact, however, the investor's tax burden is lower, as he will not have to pay tax on dividends. 
Thus, the use of debt financing instead of equity financing can provide economic benefits to both sides of it. The company that raise funds uses the tax shield and reduces the tax burden. For investors the problem of double income taxation erases.

In addition to these considerations, there may be other tax based motives for the replacement of equity financing by debt one, and moreover both from the part of borrower and the lender that depends on the country's tax system framework. For example, in the US tax practice of the middle of the last century the following advantages of debt financing over the equity one were outlined (Kliston, 1959):

a) For tax purposes, losses, if incurred, are preferable in the form of bad- debt deductions than in the form of capital losses on stock;

b) Tax-free recovery of capital, in the form of return of loans out of earnings of the corporation, maximizes tax savings for the corporation and the owners;

c) Stepped-up depreciation may be provided by the sale of depreciated assets owned by individual stockholders to the corporation for debt, on the basis of fair market value, maximizing the corporation's deductions, and after-tax profits.

At the same time, the subject method of structuring the company's capital affects the size of the declared taxable income, which in turn affects the amount of taxes paid. In this regard, it is clear that the financing of companies through loans instead of financing at the expense of equity capital leads to lower tax revenues. Thus, the need to control these relations at the regulatory level becomes clear.

Motivated by tax considerations the debt financing in form but stock capital in content was called hidden capitalization (Thin capitalization, 2010).

It should be borne in mind that a high value of financial leverage can only be an indication, but not a proof of hidden capitalization mechanisms use. This indicator may follow from the specifics of the company's financial policy based on other than tax considerations (Polezharova, 2011).

Aside of that, the ability of any enterprise to attract debt capital in the required quantities and at the mid-market conditions is limited and is determined by its reserve borrowing capacity (Kovalev, 2009. P. 280). Increasing the share of debt capital is associated with an increase of the company's financial risk and therefore reduces the reserve debt potential. The decision to grant or not grant loan to a company is based on the ratio of its own and borrowed funds. However, the problem of increasing the debt capital beyond the limits of reserve debt potential is withdrawn in case of transaction between interdependent entities. Financing issues become even more important on emerging financial markets with weak-form efficiency (Darushin at al., 2016).

The practice of equity capital replacement by the debt one in order to reduce the overall tax burden of the group of companies was named "thin capitalization". In general, the thin capitalization is considered as one of the forms of a more general concept of hidden capitalization.

A classic example demonstrating the essence of thin capitalization is a description of the use of this mechanism in the framework of a group of companies where financing of a subsidiary by a parent company takes place. The operation of parent and subsidiary companies as a single entity within the group allows us to consider their tax liabilities in aggregate. In this case, we can clearly see the effect of the total reduce of tax payments when substituting of equity capital by the debt to its shareholders in such conditions where tax savings on an income tax percentage and income tax received as the interest are below the income tax rate in total with a tax on dividends. 
Even more opportunities to obtain tax benefits arise when the group's activities are transnational in nature, and parent company with its subsidiary are located in different tax jurisdictions (Polezharova, 2011). Selection of different countries of the parties involved in transaction imposes additional conditions on taxation procedure. The interest paid by a company-borrower to a foreign company-lender is taxed, as a rule, at the source of payment, i.e. in the country of the borrower's location. Under certain conditions, taxation of interest at a source place can be reduced or reduced to zero, and will be carried out in the country of lender's location. Achieving additional savings on the combined taxes paid by a group of companies is possible if the interest paid to a foreign company is taxed at a rate lower than in the country of the borrower, when basing the first in a jurisdiction with low tax.

These considerations lead to the conclusion that the use of thin capitalization mechanisms leads to lower tax revenues. As a result, the fiscal interests of the state are unprotected.

Moreover, the thin capitalization as a form of tax planning leads to the fact that the transactions same in the economic consequences are taxed not equivalently and thus the principles of tax equity are violated (Sinelnikov-Murilev and Shkrebela, 2011, p. 59-60).

The violation of justice principle lies in the fact that the possibility of one of the two business entities to use the benefits of thin capitalization causes the payment by the first party of the less tax than an entity that received the same income, dispose the same economic position, but doesn't have the ability to use tax planning.

Given that the implementation of tax planning and thin capitalization in particular implies certain fixed costs for its development, the cost coverage will be achieved in case of largescale transactions and, consequently, the tax benefits. This fact means that in absence of restrictions on the use of thin capitalization the subjects with higher income probably pay less tax than the subjects with lower revenue.

In addition, it is important to note that the application of the thin capitalization practices may take place in the interests of major shareholders to the detriment of the minor. So, the assignment of ownership of one shareholder by others may take place that is connected with a reduction in company profits, and, accordingly, the base for the dividends payment. Besides that, the decline in profit margins can adversely affect the shares profitability of a financed company and, consequently, lead to the loss of the capitalized shareholders' income.

\section{Approaches and methods of thin capitalization regulation}

The generally accepted international practice aimed at countering tax payments minimization through thin capitalization, is fixing special rules that restrict the deduction of interest on over-indebtedness on the level of national legislation.

From an economic point of view, the idea underlying the thin capitalization rules, is that the company is not able to carry out transactions without having sufficient equity. Under the thin capitalization a company-borrower receives the loan funds in the amount significantly exceeding its own capital. When organizing such a transaction on the open market a size of the loan provided by an independent vendor, who take into account the adequacy of the own funds of the borrower, would have been different. Thin capitalization rules provide for conversion of debt tools into capital increase or interest payments into dividends and their corresponding taxation.

In addition, the thin capitalization rules usually apply to interest paid in respect of foreign shareholders or affiliated parties, but in some countries there is a possibility of their application with respect to interest income, which is also paid to domestic interdependent lenders. 
Thin capitalization rules typically operate by means of one of two approaches: (Thin capitalization legislation):

a) determining a maximum amount of debt on which deductible interest payments are available;

b) determining a maximum amount of interest that may be deducted by reference to the ratio of interest (paid or payable) to another variable (earnings stripping approach).

The regulation of the thin capitalization based on the first approach is the most common practice. Interest held from the value of the loan exceeding the limit, are not deductible for tax purposes.

Countries take different approaches to determining the maximum amount of debt that can give rise to deductible interest payments, but there are generally two broad approaches:

1) arm's length approach;

2) ratio approach.

Under the first approach, it is acknowledged that the maximum value of "permitted" debt is such an amount that an independent lender would have provided the company on market conditions with a similar transaction, i.e. in such circumstances, as if the companies were "at arm's length". First of all, this approach is based on the review of the individual characteristics of the company to determine its creditworthiness or ability to obtain a loan from independent lenders. In addition, the rule of "arm's length" often concerns establishing the loan amount the borrower would have received if the lender was an independent economic entity, functioning "at arm's length. Yet the amount of interest on the excess of the loan, which could be obtained by the borrower on the open market over a loan, which would be really granted is not allowed for deduction.

According to the second approach, the determination of a debt limit value, as discussed, is based on a predetermined ratio. The ratio of debt to equity (also known as debt to equity ratio) indicator is particularly useful. In some cases, a ratio of capital to all the company's assets is used. It is also possible to use ratios, calculated according to the data taken not from the analyzed borrower, but from the group of companies, which the borrower is the part of. In part of numerical value of the ratio as well as debt and equity treatment the implementation of this approach in various countries also occurs in different ways. The most controversial issue is the establishment of appropriate financial ratios for debt-to-equity ratio, which is in the range from 1.5-1 to 5-1 in world practice (Sinelnikov-Murilev and Shkrebela, 2011, p. 62).

The rules based on this approach can act in addition to the principle of "arm's length" or alternatively. In the states where the ratio is established in accordance with the principle of "arm's length", they define so-called "safe harbor", i.e. conditions, the implementation of which dismisses the claims of tax authorities. This means that when the estimated coefficient meets the limiting value, the loan interest will be allowed for deduction. The interest outside the boundaries of the "safe harbor" is potentially not deductible if the taxpayer will not prove that the excess corresponds to the principle of "arm's length". In several other countries the established relation is applied automatically. However the predetermined ratio can both reflect and not reflect the implementation of the transaction "at arm's length", i.e., loan market conditions.

Each of the above approaches has its advantages and disadvantages in terms of effectiveness in limiting the deductibility of interest, as well as tax administration. 
The advantage of the "arm's length" rule is that its use allows to obtain the value of the loan the most close to the size of the loan the company could actually obtain on mid-market conditions in the course of its business activities.

The obvious disadvantage of the "arm's length" rule is the high labor-intensiveness of its implementation. To use it, a tax inspector has to understand the lender's policy of determining the creditworthiness of a particular borrower, and find comparable transactions. A significant drawback of this method is the high dependence of the audits results on actions of tax bodies officials, as well as the unpredictability of the amounts recognized as unjustified tax benefit as well as the amounts qualified as dividends.

The advantage of fixed ratio method is the simplicity of its implementation, low tax bodies resources costs as well as ensuring the certainty of tax implications and litigation costs.

The apparent disadvantage of this method lies in the fact that its content does not reflect the real economic situation. The fixed ratio method is based on inflexible, unchanging standards as laid down in the ratio, which do not always take into account the particular market conditions of the transaction and industry's specifics. In addition, its use can lead to discriminatory application on companies-members of transnational corporation, because it implies, as a rule, a limited circle of lenders whose loans are regulated by the thin capitalization rules and foreign affiliated parties.

It should be noted that such rules based on a fixed ratio method are traditionally called thin capitalization rules. Other approaches relate to the rules on interest deduction limitations. Development of modern economic and financial systems, in particular, cyber market (Voronov and Ivanov, 2016) and digital economy, cause the joint action to regulate tax base erosion and profit shifting, including thin capitalization rules.

Generally, in $38 \%$ of the countries worldwide the fixed ratio method approach is used, in $12 \%$ the other approaches are used, in 50\% of the countries there is no specific regulation of the thin capitalization (Worldwide Tax Summaries Online). In other words, despite the relatively recent history of tax regulation of thin capitalization, the half of the countries worldwide has special rules governing this area of economic relations.

\section{Financial innovation to overcome the effects of thin capitalization regulation}

The main factor forcing taxpayers to use the methods of covert capitalization are tax asymmetries. In this case, they appear in different approaches to the taxation of payments on various capital sources in the difference between interest rates for different income types. The tendency to regulate this area causes taxpayers to use new methods of tax planning. Including through the use of new hybrid instruments that contain characteristics of both equity and debt financing.

The most famous example of the hybrid financing are convertible bonds. In the classic version while being redeemed they can be changed to a fixed number of shares of the same issuer, i.e. allow to convert loan capital into equity. Convertible bonds have been used on the financial markets since the middle of the XIX century and were originally used as a speculative tool (Markham, 2002. P. 161). However in recent years they have become a really popular instrument. Without going into details on all of their advantages, we would like to note that the use of the convertible bonds allows the issuer to temporarily (during the bonds circulation term) use the loan capital instead of equity. Accordingly, during this period, the issuer uses all the advantages of thin capitalization on market conditions.

In addition to the classic convertible bonds, when investor makes a decision on the change to shares, a number of variations are used worldwide: 
- Reverse convertible bonds, in which investor is obligated to make the conversion if the share price falls below the set value.

- Contingent convertible bonds (CoCo bonds) are a variant of the classic convertible bonds, however, the possibility of converting them is dependent on any additional conditions. For example, it can take place at certain time when shares price reaches a specified level. Such a product may include a variety of exotic options associated with other characteristics. Such bonds have appeared on the US market in late 1999, and by 2003 accounted for about $70 \%$ of all new convertible issues (Fabozzi, 2007, p. 433).

Note that although the convertible bonds represent the instrument of hidden capitalization, they cannot be considered as an example of thin capitalization. In this sense, they are not subject to special tax regulations. However, in the world practice it is common to use the tools that by their characteristics are subject to thin capitalization rules of regulation, but allow to bypass some restrictions.

For example, a new type of financial instrument is used on the U.S. financial market that combines the characteristics of preference shares and bonds - trust-preferred securities (TRuPS). These securities are preference shares issued by a specially created trust, the assets of which are formed by providing long-term debt financing of the emission initiator. The role of the initiator is mainly played by a large banking holding, which is planning to attract longterm capital without the need to issue the preference shares.

To start the emission the initiating bank establishes trust, with $100 \%$ of the common shares still in its possession. The preference shares emitted by the trust are placed among the investors. The money received from the emission is granted to the bank in the form of a loan. This loan refers to the subordinated debentures of the bank, without collateral. The terms of the loan (fixed or floating rate) correspond to the parameters which the Trust issued the preference shares with. In the future, the funds received from loan in the form of interest and in the manner of its redemption, are transferred to investors as dividends. With regard to the trust, it plays a technical role in this scheme, allowing the parties to overcome tax limitations. As a result, the initiating bank attracts long-term funding with the maintenance costs subject to the tax shield. Given the fact that the debt is subordinated in relation to the rest of the loan capital, investors receive a instrument comparable in terms of income payment with the preference share of the bank. At the same time in case of bank liquidation, it will have precedence over shares.

It should be noted that for the initiating bank the use trust-preferred securities is associated with higher cost in comparison with other forms of debt financing. This is due to the fact that investors take on extra risks which must be compensated by the higher returns. However, when compared financing with the cost of shares, it seems be lower for the emitter because he can use the tax shield. In fact, this tax savings system compensates the excessive rate the investor requires.

A feature of the trust-preferred securities is the pre-set date of their maturity, which corresponds to the loan period and constitutes at least 30 years (Trust Preferred Security (TruPS)). Moreover, the terms of emission may provide an option for the emitter to review and cancel the shares, starting from a certain date. In financial practice the scheme is also used in which the value of the dividend is not fixed for the entire term but for a certain period (usually 5 years).

Since their introduction in 1993, the trust-preferred securities were limitedly used in some large banking holdings and investment companies, but the change in US Federal Reserve's 
regulatory requirements in 1996 made this instrument available to a larger number of participants (Schwartz, 2003).

In 1996, the FRS allowed the bank holdings to include preferred debt securities in the calculation of the Tier I capital, that, in fact, equated them to common shares in terms of the bank's capital formation. Thus, despite the fact that these securities are formally the bank's debt, they are not considered in the calculation of required capital ratios. This rule applies to all financial institutions within a banking holding. Accordingly, the initiating bank attracts debt financing for a longer term, with the sums involved not taken into account in the calculation of capital requirements. At the legislative level, this rule was enshrined in the 2010 Dodd-Frank Wall Street Reform and Consumer Protection Act (Dodd-Frank Wall Street Reform and Consumer Protection Act).

As we can see, TRuPS are a classic example of the use of thin capitalization mechanism. The parent company (bank) attracts debt financing from its subsidiary (Trust), which in its essence is an equity. However, the parties applying the instrument may use certain tax advantages. The initiating Bank applies tax shield to the amount of interest payments. In addition, the use of TRuPS does not impair the characteristics of its capital. Investors can materialize the benefit consisting in lower rates applicable to dividends.

From our point of view, this example illustrates the fact that the economic benefits of the state meant to increase the stability of the banking system exceed its fiscal interest, as well as tax administration costs.

\section{Conclusions}

To sum up what has been said, it should be noted that using new tax regulation tools does not always lead to the effects meant initially by the state. The emergence of new tax restrictions may affect the economic activity and stability of functioning of individual markets and institutions. On the other hand, the experience shows that the appearance of additional restrictions is a factor of financial relations development, the introduction of new ways of overcoming those restrictions. In particular, new financial technologies and instruments appear as the result. This, in turn, is a factor of tax administration costs increase that can lead to the evening-out of the benefits from additional tax revenues.

\section{Literature}

Darushin, I. A., Lvova, N. A., Ivanov, V. V., Voronova, N. S. (2016). "The Russian Stock Market: Is It Still Efficient? Innovation management and education excellence vision 2020: from regional development sustainability to global economic growth. The 27th IBIMA conference proceedings, pp. 818-828.

Dodd-Frank Wall Street Reform and Consumer Protection Act, available on-line at www.gpo.gov/fdsys/pkg/PLAW-111publ203/html/PLAW-111publ203.htm (accessed 20 September 2016).

Fabozzi, Frank J. (2007). Bond markets, analysis and strategies. 6th ed. New Jersey: Pearson Education.

Kliston, T. S. (1959). Review of Thin capitalization by M. M. Lore. The Journal of Finance, no. 3, pp. 437-438.

Kovalev, V. V. (2009). The Balance-Sheet Analysis: How to Understand the Balance-Sheet. Moscow: Prospect. (in Russian) 
Markham, J. W. (2002). A Financial History of the United States: From Christopher Columbus to the Robber Barons. London: M. E. Sharpe.

Polezharova, L. V. (2011). Thin Capitalization Counter Mechanism. Finansoviy zhurnal, no. 1, pp. 24-25. (IN Russian)

Schwartz, R. C. (2003). Trust Preferred Securities: They're Not Just for Big Banks Anymore! Trust the Leaders, no. 4.

Available on-line at www.sgrlaw.com/resources/trust_the_leaders/leaders_issues/ttl4/923/ (accessed 20 September 2016).

Sinelnikov-Murilev, E. V., Shkrebela, M. (2011). Improving the Income Tax in Russian Federation in the Medium Term. Moscow: Gaydar Institute Publishing.

Thin capitalisation (2010). Model Tax Convention on Income and on Capital (Full Version) available on-line at www.keepeek.com/Digital-Asset-Management/oecd/taxation/model-taxconvention-on-income-and-on-capital-2010/r-4-thin-capitalisation_9789264175181-97en\#page20 (accessed 20 September 2016).

Thin capitalization legislation. A background paper for country tax administrations (Pilot version for comments).

available on-line at www.oecd.org/ctp/tax-global/5.\%20Thin_Capitalization_Background.pdf (accessed 20 September 2016).

Trust Preferred Security (TruPS).

Available on-line at www.riskglossary.com/link/TruPS.htm (accessed 20 September 2016).

Voronov, V. S., Ivanov, V. V. (2016). The Rise of Cyber Market for Stock Art: Assets Aggregation and the Wealth of Mass Creativity. Innovation management and education excellence vision 2020: from regional development sustainability to global economic growth. The 27th IBIMA conference proceedings, pp. 537-545.

Worldwide Tax Summaries Online.

available on-line at taxsummaries.pwc.com/uk/taxsummaries/wwts.nsf/ID/PPAA-85RDKF (accessed 20 September 2016). 